\title{
Physical and Chemical Evaluation of Osmotic Dehydrated, Dried and Irradiated Pineapple Pearl
}

\section{Avaliação Física e Química da Desidratação Osmótica, em Abacaxi Pérola Seco e Irradiado}

\author{
Rita de Cássia Batista Silva Turíbio \\ Universidade Federal do Tocantins - UFT, Palmas, TO \\ ritadecassia@mail.uft.edu.br \\ Adriana Régia Marques de Souza
}

Escola de Agronomia, Universidade Federal de Goiás - UFG, Goiânia, GO

adriana.souza@pq.cnpq.br

Yasmini Portes Abraham Silva

Universidade Federal de Goiás - UFG, Goiânia, GO

yasminipas@hotmail.com

Celso José José de Moura

Escola de Agronomia, Universidade Federal de Goiás - UFG, Goiânia, GO celsojose@gmail.com

Katiuchia Pereira Takeuchi

Universidade Federal do Mato Grosso - UFMT, Cuiabá, MT

katiuchia.takeuchi@pq.cnpq.br

Danielle Pires Nogueira

Escola de Agronomia, Universidade Federal de Goiás - UFG, Goiânia, GO nogueira.dp@gmail.com

Tatiane de Souza Mendonça

Universidade Federal do Tocantins - UFT, Palmas, TO

tatianenft@gmail.com

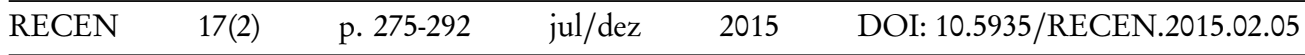


Revista Ciências Exatas e Naturais, Vol. 17, n² 2, Jul/Dez 2015

\author{
Valter Arthur \\ Centro de Energia Nuclear na Agricultura - CENA, Piracicaba, SP \\ arthur@cena.usp.br
}

\begin{abstract}
The combined methods technology bases itself in the synergic interaction of different preservation methods to maintain food quality. The purpose of this work was to evaluate the effects of radiation doses $(0,75$ and $1,5 \mathrm{kGy})$ in the physical and chemical properties of osmotically dehydrated, and dried pineapple during storage (0, 14, 28 and 56 days). Moisture content, water activity, soluble solids content, total acidity, $\mathrm{pH}$, color, and texture were evaluated. The radiation levels did not affect moisture or water activity, although, storage time affected the values. The soluble solids, total acidity and $\mathrm{pH}$ were practically constant during storage time. The radiation doses affected the samples color, reducing the $\mathrm{L}$ and $\mathrm{b} *$ parameters. The texture, for rupture strength as well as rupture work, throughout time, and radiation doses was affected, both variables caused a reduction in crunchiness and hardness of the pineapple. The irradiation was an excellent combined method to increase storage time of osmotically dehydrated and dried pineapple.
\end{abstract}

Keywords: combined methods; radiation; texture.

Resumo: A tecnologia de métodos combinados baseia-se na atuação sinérgica dos diferentes métodos de conservação para manter a qualidade dos alimentos. O objetivo deste trabalho foi avaliar os efeitos de doses de radiação $(0.75$ e 1.5 kGy) nas características físicas e químicas do abacaxi, tratado com desidratação osmótica e seco, durante o armazenamento $(0,14,28$ e 56 dias). Foram avaliados umidade, atividade de água, teor de sólidos solúveis, acidez total, $\mathrm{pH}$, cor e textura. Os níveis de radiação não afetaram a umidade nem a atividade de água, porém o tempo de armazenamento alterou os valores. $\mathrm{O}$ teor de sólidos solúveis, acidez total e $\mathrm{pH}$ mantiveram-se praticamente constantes durante o tempo de armazenamento. As doses de radiação afetaram a cor das amostras, reduzindo os parâmetros L e b*. A textura, tanto para a força de ruptura quanto para o trabalho de ruptura, no decorrer do tempo, e nas doses de radiação, 
foi afetada, a dureza e a crocância do abacaxi desidratado diminuíram em ambos. A irradiação foi um excelente método combinado para prolongar o armazenamento do abacaxi tratado com desidratação osmótica e seco.

Palavras-chave: métodos combinados; radiação; textura.

\section{Introduction}

Pineapple has a thick inedible peel and a large crown, these characteristics lead to higher transportation cost. Therefore, it can be interesting to process it into a readyto-eat product, increasing value, as well as attracting consumers. However, processing the fruit increases metabolic activities reducing shelf life [1]. Pineapple is a highly appreciated fruit, both by its sensory and nutritional qualities. It is rich in vitamin C, vitamins of complex B, carbohydrates, sugars, and also minerals as calcium, manganese, potassium, magnesium, iron as well as fibers. It also contains bromelain, a proteolytic enzyme, which aids in reducing inflammations and helps digestion. Water is present in high concentrations in agricultural products, and most of the deterioration processes are influenced by the concentration and mobility of water. Pineapples, in particular, due to its high moisture content make them susceptible to mold growth. An alternative to prolong the post-harvest life of this product is the water removal. Although, conventional drying with hot air is expensive, requiring a large quantity of energy to change the phase of water from liquid to vapor. Thus, osmotic dehydration (O.D) can be applied to partially remove water, improve nutritional features and flavor [2].

The O.D. is a processing technique commonly applied to fruits and vegetables. It partly removes the water of the product by immersing it in an aqueous hypertonic solution. It causes a reduction in the water activity reducing the potential microbiological growth and increasing shelf life [3]. O.D. can be applied as a method to increase shelf life of minimally processed food, as well as improving nutritional value. As a pretreatment to drying, O.D. can reduce the moisture content of a plant by approximately 50\%. It can also reduce aroma losses, enzymatic browning, increase 
sensory acceptance, and the retention of nutrients [4]. According to Valente [5], the drying process, for involving considerably high temperatures for fruits, for a long period, alters food composition, causes loss of nutrients and very significant structure and color alterations. For that matter, many authors have been suggesting the use of osmotic dehydration as a pretreatment to drying. The O.D. is an efficient process in improving the final quality of the product. It reduces the loss of nutrients that are volatile and sensible to high temperatures during the drying process. The O.D. also helps maintaining a texture similar to the fresh product one.

The application of ionizing radiation in food is a technique that has been largely studied. Its effects on the food depend strictly on the applied dose (specific for each product), the ripeness stage and the quality of the raw material [6]. Therefore, since every product behaves in a different way, it is necessary to make studies to determine the ideal radiation dose to each product, by evaluating the effects of different applied doses [7].

The ionizing radiation, when applied in low doses, has shown itself as an effective method to enlarge the commercial life of fruits, because it slows the ripening and senescence processes. Although, like in any post harvesting treatment that intends achieving better quality maintenance, to obtain satisfying results it is necessary that the applied dose of ionizing radiation does not impair the main quality characteristics of the fruit. That is why suiting the ideal dose is a challenge to all the researchers, since the results can be influenced by many intrinsic and extrinsic factors. Also, applying an inappropriate dose can cause many unwanted results to the fruit, like irregular ripening, darkening of the pulp and peel, and also flavor alterations [8].

Along with other traditional processing or preserving food methods, the food irradiation technology has been gaining attention across the world. Since the irradiation is a "cold process", that is, it does not increase substantially the temperature of the product being processed; the nutrient losses are small, usually, significantly smaller than the ones associated to other preserving methods, like drying and pasteurization [9].

The combined methods technology is a tendency that has been growing worldwide and is based on the synergistic interaction of the different preserving methods. The 
combination of different preserving techniques keeps the food quality, guarantying its microbiological safety and stability [10]. The aim of this work was to evaluate the effects of different doses of radiation over the physicochemical and physical characteristics of osmotic dehydrated and dried pineapple in different storage times.

\section{Materials and methods}

\subsection{Raw material preparation}

Pineapples with uniform ripeness degree were obtained in the local commerce in Goiânia (Goiás, Brazil). The ripeness was visually evaluated.

The pineapples were washed and sanitized in chlorine $100 \mathrm{ppm}$ solution for 15 minutes. They were, then, drained and peeled. The pineapples were sliced in round pieces of approximately $1,5 \mathrm{~cm}$ thickness. Each slice was cut in fourths, removing the central cylinder.

The following analyses were done for the unprocessed raw material: moisture content, total soluble solids content, $\mathrm{pH}$ and total acidity, according to the methods described by the Adolfo Lutz Institute [11]. Since the raw product was not used as control, the water activity was not tested.

\subsection{Osmotic dehydration and drying}

Commercial sucrose was used in the osmotic dehydration, provided by the Anicuns S. A. plant, as the osmotic agent in the concentration of 470 g. $\mathrm{L}^{-1}\left(47^{\circ} \mathrm{Bx}\right)$. The O.D was conducted at the following conditions: temperature of $50^{\circ} \mathrm{C}$, agitation of $100 \mathrm{rpm}$, for one hour and 45 minutes, in a 3:1 ratio (solution: sample), as suggested by Dionello et al [12]. After the O.D., the pineapples were removed from the O.D. solution and washed in running water at $18^{\circ} \mathrm{C}$ for 1 minute, to remove the osmotic solution layer adhered to the surface that could affect the water loss in the drying process, and drained in paper towel.

The drying was then conducted in oven with air circulation, at $60^{\circ} \mathrm{C}$ for 24 hours. After the drying, the pineapples were packed in polypropylene packages, containing $50 \mathrm{~g}$ of product each, and then separated in three batches, according to the radiation 
dose to be applied.

The analyses done for the raw material were repeated (moisture content, total soluble solids content, $\mathrm{pH}$, total acidity), for the pineapple after the O.D. and after the O.D and drying.

\subsection{Irradiation}

The dried pineapples were irradiated at the Centro de Energia Nuclear na Agricultura (CENA/USP), in Piracicaba (SP), using a GamaCell irradiator with a 60Co source (cobalt-60). The radiation doses applied were $0 \mathrm{kGy}$ (control sample), 0.75 $\mathrm{kGy}$ and $1.5 \mathrm{kGy}$.

\subsection{Physicochemical and physical analyses}

After the irradiation process, the physicochemical analyses were held in various times $(0,14,28$ and 56 days). The aim was to evaluate the affects of the irradiation over the pineapples during continuous storage. The samples were stored at constant temperature of $10^{\circ} \mathrm{C}$, relative moisture content $85-90 \%$, away from light. All the analyses were done in triplicates.

The determinations were the following: moisture content, water activity (AquaLab Series 4, Decagon, USA), total soluble solids content, total acidity and $\mathrm{pH}$ (Hanna Instruments HI 9924), according to the methodology described by the Adolfo Lutz Institute [11].

\subsubsection{Color}

The instrumental color of the pineapple slices was determined by direct reading on the ColorQuest II colorimeter (Hunter LAB, USA), using the CIELab color space. Before starting the processing of the samples, the equipment was subjected to calibration, by placing the gun read in the calibration plate center, then pressing the calibrate key and then the measure key. After waiting 3 flashes of light, the equipment was ready for use. The samples were whole pieces of dried pineapple that were placed directly after the light beam exit. Due to the high variability inherent of this 
kind of product, the analysis was repeated 5 times (a different slice to every measure), choosing the samples randomly.

\subsubsection{Texture}

The texture parameters were analyzed with a texturometer (Texture Analyzer, TA.XT-Plus, Stable MicroSystems, Surrey, UK), using a probe HDP/BS (knife), manufactured by Stable MicroSystems. The test speeds were as following: pretest $=3$ mm.s $\mathrm{s}^{-1}$, during test $=1 \mathrm{~mm} \cdot \mathrm{s}^{-1}$, post test $=10 \mathrm{~mm} \cdot \mathrm{s}^{-1}$. The sample was compressed until $300 \%$ of the initial height, to guarantee its complete rupture. The software of the equipment (Exponent Lite, version 6, 1, 4, 0 - Stable MicroSystems) provided then the numeric values of Rupture force ( $F_{\text {rup }}$, in Newtons) and the Work for rupture $\left(\mathrm{F}^{*} \mathrm{~d}\right.$, Newton $\times$ meter), for each reading. The rupture force represented the maximum peak of the $\mathrm{F}^{*} \mathrm{~d}$ curve, and the work for rupture represented the area under the graph $\mathrm{F}^{*} \mathrm{~d}$ to the rupture point. This analysis was done in seven repetitions for each treatment. Fruits have great texture variability, specially dried ones, what causes a low reproducibility for this kind of analysis $[13,14]$.

\subsection{Statistical analyses}

The results obtained in the physicochemical and physical analyses underwent variance analysis (ANOVA) and the Tukey test, to the level of 5\% of probability, using the Microsoft Excel program.

\section{Results and discussions}

\subsection{Fruit characterization, before and after the O.D.}

Table 1 shows the results of the analysis done in the raw pineapple (R), osmotically dehydrated pineapple not dried (OD), and dried (DS). The soluble solids content increased after the O.D. and drying processes, when compared to the raw pineapple. It's an evidence of the absorption of solute (sugar) by the raw material. However, this increase was lower then described in the literature. Dionello et al [12] found soluble solids content of $13{ }^{\circ}$ Brix for the raw fruit and $31.2^{\circ}$ Brix after the O.D. in samples 
treated as the ones in this study. The water loss, shown by the difference of moisture content between the raw fruit and after the O.D., was very low too, when compared to other studies.

Table 1. Analyses of the raw pineapple (R), after the O.D. (OD), and drying (DS)

\begin{tabular}{llll}
\hline \multirow{2}{*}{ Analysis } & \multicolumn{3}{l}{ Result (average \pm standard deviation) } \\
\cline { 2 - 4 } & R & OD & DS \\
\hline Moisture content $(\%)$ & $86.98^{\mathrm{a} *} \pm 0.028$ & $85.26^{\mathrm{b}} \pm 0.212$ & $9.95^{\mathrm{c}} \pm 0.346$ \\
Soluble Solids ( ${ }^{\circ}$ Brix) & $10.9^{\mathrm{c}} \pm 0.755$ & $13.5^{\mathrm{b}} \pm 0.519$ & $70.0^{\mathrm{a}} \pm 0.002$ \\
pH & $3.4^{\mathrm{c}} \pm 0.015$ & $3.5^{\mathrm{b}} \pm 0.015$ & $4.06^{\mathrm{a}} \pm 0.017$ \\
Total Acidity & $10.00^{\mathrm{b}} \pm 0.039$ & $8.09^{\mathrm{c}} \pm 0.155$ & $28.47^{\mathrm{a}} \pm 0.325$ \\
\hline
\end{tabular}

* In a same line, different letters between columns indicate statistical difference at a $5 \%$ level.

Several factors can influence the effects of O.D. on fruits, both characteristics of the raw material (fruit variety, ripeness stage, geometry after cutting) as processing characteristics (osmotic agent, temperature, agitation and duration of the process, equipment geometry). Therefore, even when analyzing the same type of fruit, different results can be obtained. Valente [5], studying O.D. in pineapple, found the following results: for the raw fruit, moisture content of $86.07 \%$, soluble solids content of $13.43^{\circ} \mathrm{Brix}, \mathrm{pH}$ of 4.14 ; and after the O.D. (using sucrose as the osmotic agent, concentration of $40^{\circ} \mathrm{Brix}$, at $35^{\circ} \mathrm{C}$ for 120 minutes and under an agitation of $100 \mathrm{rpm}$ ), moisture content of $76.20 \%$.

The total acidity reduction is also noticeable, due to the loss of organic acids. They are easily removed from the fruit, along with the water, because of their low molecular weight. According to Valente [5], in the osmotic treatment, the mass transfer is not only characterized by the water removal from the material, but also for the natural solids loss (vitamins, minerals, organic acids, etc.) and the gain of solids from the dehydrating solution. 


\subsection{Physicochemical analyses after the irradiation}

The storage time was counted starting on the day of the irradiation process $(t=0)$, which happened 7 days after the process od O.D. and drying.

\subsubsection{Moisture content}

The moisture contents of the samples with different radiation doses applied, during the storage time evaluated, are shown in table 2.

Table 2. Moisture content of the pineapples treated with osmotic debydration and drying, subjected to irradiation, at the different storage times

\begin{tabular}{lllll}
\hline $\begin{array}{l}\text { Time (days) } \\
\text { Radiation doses }\end{array}$ & 0 & 14 & 28 & 56 \\
\hline $0 \mathrm{kGy}$ & $10.6^{\mathrm{aC} *} \pm 0.735$ & $12.3^{\mathrm{aB}} \pm 0.346$ & $14.3^{\mathrm{aA}} \pm 0.802$ & $14.1^{\mathrm{aA}} \pm 0.702$ \\
$0.75 \mathrm{kGy}$ & $9.9^{\mathrm{aB}} \pm 0.590$ & $14.5^{\mathrm{bA}} \pm 0.961$ & $14.6^{\mathrm{aA}} \pm 0.250$ & $14.5^{\mathrm{aA}} \pm 0.611$ \\
$1.5 \mathrm{kGy}$ & $10.9^{\mathrm{aB}} \pm 0.702$ & $14.1^{\mathrm{bA}} \pm 0.172$ & $15.0^{\mathrm{aA}} \pm 0.707$ & $15.4^{\mathrm{aA}} \pm 0.115$ \\
\hline
\end{tabular}

*At a given column, equal letters in different lines (lowercase letters) indicate that there is no significant difference $(\mathrm{p}<5 \%)$ between the different radiation doses.

*At a given line, equal letters in different columns (capital letters) indicate that there is no significant difference $(\mathrm{p}<5 \%)$ between the storage times.

For all radiation doses (each line on table 2), a tendency of moisture content increase through time (different columns at a given line) was observed. The moisture of the non-irradiated sample was stable after 28 days of storage, while for the irradiated samples, stabilization occurred earlier, at 14 days of storage. The moisture content of dried products can vary according to the storage conditions, due to the stabilization of the product's moisture content with the relative humidity of its storage environment, which in this study was the interior of the packaging. Since the pineapple was packed immediately after drying, the initial increase of its moisture content can be attributed to this stabilization process. Even then, the moisture content contents were kept very low throughout the evaluated period; therefore it can be considered a factor that contributes to the preservation of the product. When evaluating the effect of the radiation dose at a specific time (different lines at a given column at table 2), the only difference was observed at 14 days of storage, when the non-irradiated sample 
showed lower moisture content than the irradiated ones. It can be assumed that up until 14 days of storage, the irradiation process speeded up the moisture intake of the samples. After this time, the non-irradiated sample reached the same moisture level than the irradiated samples, and from 28 days of storage onwards the radiation dose had no significant effect on the moisture content of the product. These results imply that the irradiation process accelerates the stabilization of the moisture content of the product, possibly due to some level of rearrangement of the microscopical structure of the product caused by the irradiation that could facilitate the moisture transfer in the product.

\subsubsection{Water activity}

The water activity levels of the dried and irradiated pineapple samples, in the different storage times, are shown on table 3.

Table 3. Water activity of the osmotically dehydrated and dried pineapple samples, submited to irradiation, at different storage times

\begin{tabular}{lllll}
\hline $\begin{array}{l}\text { Time (days) } \\
\text { Radiation doses }\end{array}$ & 0 & 14 & 28 & 56 \\
\hline $0 \mathrm{kGy}$ & $0.418^{\mathrm{aA} *} \pm 0.003$ & $0.424^{\mathrm{aA}} \pm 0.001$ & $0.435^{\mathrm{aAB}} \pm 0.007$ & $0.458^{\mathrm{aB}} \pm 0.004$ \\
$0.75 \mathrm{kGy}$ & $0.429^{\mathrm{bC}} \pm 0.005$ & $0.446^{\mathrm{bA}} \pm 0.006$ & $0.445^{\mathrm{aA}} \pm 0.002$ & $0.474^{\mathrm{bB}} \pm 0.003$ \\
$1.5 \mathrm{kGy}$ & $0.435^{\mathrm{cA}} \pm 0.002$ & $0.452^{\mathrm{bAB}} \pm 0.015$ & $0.445^{\mathrm{aA}} \pm 0.005$ & $0.476^{\mathrm{bB}} \pm 0.004$ \\
\hline
\end{tabular}

*At a given column, equal letters in different lines (lowercase letters) indicate that there is no significant difference $(\mathrm{p}<5 \%)$ between the different radiation doses.

At a given line, equal letters in different columns (capital letters) indicate that there is no significant difference $(\mathrm{p}<5 \%)$ between the storage times.

An increase in water activity could be observed for the irradiated samples, when compared with the non-irradiated ones, except for 28 days of storage. This behavior can be due to a rupture of the plant cells, caused by the radiation, increasing the content of water available for reactions. Mixed results were obtained for the effect of storage time over water activity, therefore this variation can be attributed to sample variability and not to storage effects.

At all times and radiation doses, the water activity remained below the value of 0.6 , considered the threshold for the development of microorganisms [15]. There- 
fore, the product can be considered microbiologically safe during the period evaluated.

\subsubsection{Soluble solids content}

The soluble solids content values of the dried and irradiated pineapple samples during storage are presented on table 4 . Considering the raw material inherent variability, there was no significant effect of either the storage time or the radiation doses over the soluble solids content of the samples.

Table 4. Soluble solids content of the osmotically debydrated and dried pineapple samples, submitted to irradiation, during storage

\begin{tabular}{lllll}
\hline $\begin{array}{l}\text { Time (days) } \\
\text { Radiation doses }\end{array}$ & 0 & 14 & 28 & 56 \\
\hline $0 \mathrm{kGy}$ & $77.5^{\mathrm{aA} *} \pm 0.003$ & $75.0^{\mathrm{aA}} \pm 0.001$ & $72.5^{\mathrm{aA}} \pm 0.007$ & $72.0^{\mathrm{aA}} \pm 0.004$ \\
$0.75 \mathrm{kGy}$ & $78.8^{\mathrm{aA}} \pm 0.005$ & $75.8^{\mathrm{aA}} \pm 0.006$ & $73.0^{\mathrm{aA}} \pm 0.002$ & $70.0^{\mathrm{aA}} \pm 0.003$ \\
$1.5 \mathrm{kGy}$ & $83.3^{\mathrm{aA}} \pm 0.002$ & $79.0^{\mathrm{aA}} \pm 0.015$ & $75.0^{\mathrm{aA}} \pm 0.005$ & $70.0^{\mathrm{aA}} \pm 0.004$ \\
\hline
\end{tabular}

*At a given column, equal letters in different lines (lowercase letters) indicate that there is no significant difference $(\mathrm{p}<5 \%)$ between the different radiation doses.

At a given line, equal letters in different columns (capital letters) indicate that there is no significant difference $(\mathrm{p}<5 \%)$ between the storage times.

The soluble solids content of raw fruits varies throughout storage due to the ripening processes that take place. Alterations related to insoluble polysaccharides, mainly change from starch to soluble sugars, and also sugars degradation in other ripening metabolic functions are the main alterations [16]. Drying is a process that reduces these alterations, which is one of the reasons it is considered a method effective for increasing shelf life of fruit products. The results obtained in this study show that the drying process was efficient in reducing these changes and therefore contribute to increase the product shelf life.

\subsubsection{Total acidity}

The total acidity values of the dried and irradiated pineapple, on the various storage days, are shown on table 5 . The total acidity of the dried and irradiated pineap- 
ple samples presented a similar behavior to the soluble solids content. It did not vary significantly throughout storage or between the different radiation doses. In fruits the acids usually reduce with time, because they are consumed in reactions that are proper of ripening and aging. A constancy of the acids values was observed during storage time studied, indicating a smaller amount for the synthesis of new reactions. Once again, this result shows how drying contributes to increase the shelf life of the product.

Table 5. Total acidity of the osmotically dehydrated and dried pineapple samples, treated with irradiation, throughout storage

\begin{tabular}{lllll}
\hline $\begin{array}{l}\text { Time (days) } \\
\text { Radiation doses }\end{array}$ & 0 & 14 & 28 & 56 \\
\hline $0 \mathrm{kGy}$ & $32.53^{\mathrm{aA} *} \pm 0.003$ & $32.40^{\mathrm{aA}} \pm 0.001$ & $31.63^{\mathrm{aA}} \pm 0.007$ & $30.90^{\mathrm{aA}} \pm 0.004$ \\
$0.75 \mathrm{kGy}$ & $29.65^{\mathrm{aA}} \pm 0.005$ & $28.07^{\mathrm{aA}} \pm 0.006$ & $28.02^{\mathrm{aA}} \pm 0.002$ & $27.56^{\mathrm{aA}} \pm 0.003$ \\
$1.5 \mathrm{kGy}$ & $29.90^{\mathrm{aA}} \pm 0.002$ & $28.18^{\mathrm{aA}} \pm 0.015$ & $26.86^{\mathrm{aA}} \pm 0.005$ & $24.72^{\mathrm{aA}} \pm 0.004$ \\
\hline
\end{tabular}

*At a given column, equal letters in different lines (lowercase letters) indicate that there is no significant difference $(\mathrm{p}<5 \%)$ between the different radiation doses.

At a given line, equal letters in different columns (capital letters) indicate that there is no significant difference $(\mathrm{p}<5 \%)$ between the storage times.

\subsection{5 $\mathrm{pH}$}

The $\mathrm{pH}$ values for the irradiated and dried pineapple samples, on the various storage days, are displayed on table 6.

Table 6. $p H$ values of the osmotically dehydrated and dried pineapple samples, treated with irradiation, throughout storage

\begin{tabular}{lllll}
\hline $\begin{array}{l}\text { Time (days) } \\
\text { Radiation doses }\end{array}$ & 0 & 14 & 28 & 56 \\
\hline $0 \mathrm{kGy}$ & $4.18^{\mathrm{aA} *} \pm 0.003$ & $4.08^{\mathrm{aA}} \pm 0.003$ & $4.30^{\mathrm{aA}} \pm 0.015$ & $4.01^{\mathrm{aA}} \pm 0.006$ \\
$0.75 \mathrm{kGy}$ & $4.18^{\mathrm{aA}} \pm 0.005$ & $4.11^{\mathrm{aA}} \pm 0.001$ & $4.34^{\mathrm{aA}} \pm 0.002$ & $4.04^{\mathrm{aA}} \pm 0.004$ \\
$1.5 \mathrm{kGy}$ & $4.17^{\mathrm{aA}} \pm 0.002$ & $4.14^{\mathrm{aA}} \pm 0.005$ & $4.32^{\mathrm{aA}} \pm 0.007$ & $4.07^{\mathrm{aA}} \pm 0.004$ \\
\hline
\end{tabular}

*At a given column, equal letters in different lines (lowercase letters) indicate that there is no significant difference $(\mathrm{p}<5 \%)$ between the different radiation doses.

At a given line, equal letters in different columns (capital letters) indicate that there is no significant difference $(\mathrm{p}<5 \%)$ between the storage times. 
The $\mathrm{pH}$ presented a behavior similar to the total acidity, showing no statistical variation throughout the evaluated time and not being influenced by the radiation dose. In fruit products, small variations in $\mathrm{pH}$ may cause great flavor changes, therefore the fact that irradiation did not influenced this parameter can be considered positive for the conservation of the product.

\subsubsection{Color}

The results of the instrumental color of the dried and irradiated pineapple samples during storage are displayed on tables 7 and 8 . The predominant color in pineapple pulp, even after drying, is yellow, represented by the $b^{*}$ parameter (yellow-blue). Therefore, for this product the parameter $b *$ is much more representative than the $\mathrm{a}^{*}$ (green-red). For this reason, only the L (Table 7) and $\mathrm{b} *$ (Table 8) values were evaluated, as suggested by Sato et al [14].

Table 7. L parameter of the osmotically dehydrated and dried pineapple samples, treated with irradiation, throughout storage

\begin{tabular}{lllll}
\hline $\begin{array}{l}\text { Time (days) } \\
\text { Radiation doses }\end{array}$ & 0 & 14 & 28 & 56 \\
\hline $0 \mathrm{kGy}$ & $58.41^{\mathrm{aA}} \pm 1.67$ & $53.72^{\mathrm{aAB}} \pm 5.06$ & $48.29^{\mathrm{abB}} \pm 2.85$ & $48.1^{\mathrm{aB}} \pm 2.13$ \\
$0.75 \mathrm{kGy}$ & $52.71^{\mathrm{bA}} \pm 2.15$ & $50.07^{\mathrm{aA}} \pm 2.92$ & $45.72^{\mathrm{aB}} \pm 3.59$ & $42.74^{\mathrm{bB}} \pm 2.13$ \\
$1.5 \mathrm{kGy}$ & $52.61^{\mathrm{bA}} \pm 1.52$ & $50.86^{\mathrm{bA}} \pm 1.89$ & $42.5^{\mathrm{bB}} \pm 4.40$ & $39.16^{\mathrm{bB}} \pm 2.83$ \\
\hline
\end{tabular}

*At a given column, equal letters in different lines (lowercase letters) indicate that there is no significant difference $(\mathrm{p}<5 \%)$ between the different radiation doses.

At a given line, equal letters in different columns (capital letters) indicate that there is no significant difference $(\mathrm{p}<5 \%)$ between the storage times.

Lower $\mathrm{L}$ values indicate lower luminosity, that is, a darker product. The radiation doses significantly affected this parameter, since a significant reduction in the $L$ values was observed for the irradiated samples, at all times evaluated. Similar effect was shown by the storage time, with all samples becoming darker (lower L value) as time passed.

Lower values of the $b^{*}$ parameter indicates a weaker yellow color. Both irradiated samples showed a decrease in its value during storage, while for the non-irradiated 
Revista Ciências Exatas e Naturais, Vol. 17, n² 2, Jul/Dez 2015

Table 8. $b^{*}$ parameter of the osmotically dehydrated and dried pineapple samples, treated with irradiation, throughout storage

\begin{tabular}{lllll}
\hline $\begin{array}{l}\text { Time (days) } \\
\text { Radiation doses }\end{array}$ & 0 & 14 & 28 & $\mathbf{5 6}$ \\
\hline $0 \mathrm{kGy}$ & $28.98^{\mathrm{aA}} \pm 1.06$ & $30.73^{\mathrm{aA}} \pm 1.36$ & $29.08^{\mathrm{aA}} \pm 2.46$ & $28.56^{\mathrm{aA}} \pm 3.32$ \\
$0.75 \mathrm{kGy}$ & $31.86^{\mathrm{aA}} \pm 1.05$ & $30.23^{\mathrm{aA}} \pm 0.65$ & $27.98^{\mathrm{aB}} \pm 1.67$ & $26.85^{\mathrm{a}} \pm 3.43$ \\
$1.5 \mathrm{kGy}$ & $30.32^{\mathrm{aA}} \pm 1.31$ & $27.76^{\mathrm{bB}} \pm 2.01$ & $25.12^{\mathrm{bB}} \pm 1.92$ & $24.95^{\mathrm{aB}} \pm 4.11$ \\
\hline
\end{tabular}

* At a given column, equal letters in different lines (lowercase letters) indicate that there is no significant difference $(\mathrm{p}<5 \%)$ between the different radiation doses.

At a given line, equal letters in different columns (capital letters) indicate that there is no significant difference $(\mathrm{p}<5 \%)$ between the storage times.

sample the $b^{*}$ parameter did not significantly change over time. For the irradiated samples, the lower dose $(0.75 \mathrm{kGy})$ caused a change at day 28 , but the stronger dose (1.5 kGy) caused the change to start earlier (at 14 days). This result shows that the radiation dose affects the color maintenance of dried pineapple, with higher doses causing color losses at an earlier storage time. Changes in the color of fruits, are caused mainly due to Maillard reactions, therefore it can be assumed that the irradiation process accelerates the start of these reactions in the product.

\subsubsection{Texture}

The rupture strength (Table 9) indicates that the irradiation process affected the texture of the product, and that the bigger the dose, less strength applied to rupture the slice of osmotically dehydrated and dried pineapple. The storage time also affected this behavior indicating a softening of the fruits as early as 14 days for the irradiated sample and 28 days for the non-irradiated. Similar results were found by Silva, Silva and Spoto [8] employing doses of 100 and 150 Gy in pineapples that were refrigerated and stored for 30 days.

The $\mathrm{F}_{\text {rup }}$ values observed in this work were quite high when compared to other dried fruits. Oliveira [13] found $\mathrm{F}_{\text {rup }}$ values varying from approximately 30 to $60 \mathrm{~N}$ for dried banana (Musa paradisiaca), while in this work the values varied from 65 to $177 \mathrm{~N}$, approximately. This is due to the great amount of fibers in the pineapple that contribute to keep the products structure, making its rupture harder. 
Table 9. Rupture force (Newton) of the osmotically dehydrated and dried pineapple samples, treated with irradiation, throughout storage

\begin{tabular}{lllll}
\hline $\begin{array}{l}\text { Time (days) } \\
\text { Radiation doses }\end{array}$ & 0 & 14 & 28 & 56 \\
\hline $0 \mathrm{kGy}$ & $177^{\mathrm{aA}} \pm 63^{*}$ & $171^{\mathrm{aA}} \pm 27$ & $120^{\mathrm{aB}} \pm 27$ & $104^{\mathrm{aC}} \pm 20$ \\
$0.75 \mathrm{kGy}$ & $163^{\mathrm{bA}} \pm 25$ & $146^{\mathrm{bB}} \pm 24$ & $92^{\mathrm{bC}} \pm 17$ & $65^{\mathrm{b}} \pm 7$ \\
$1.5 \mathrm{kGy}$ & $13^{\mathrm{cA}} \pm 22$ & $110^{\mathrm{cB}} \pm 11$ & $100^{\mathrm{bB}} \pm 12$ & $66^{\mathrm{bC}} \pm 9$ \\
\hline
\end{tabular}

*At a given column, equal letters in different lines (lowercase letters) indicate that there is no significant difference $(\mathrm{p}<0.05)$ between the different radiation doses. At a given line, equal letters in different columns (capital letters) indicate that there is no significant difference ( $\mathrm{p}$ $<0.05$ ) between the storage times.

Similar results were observed for the parameter work (Table 10), which was higher for the non-irradiated sample than for the irradiated ones at all times studied. Since this parameter is related to the amount of energy spent to bite the product [14], this result shows that the irradiation probably caused a destruction of the cell structures that contribute to the firmness of the product, making the fruit softer.

Table 10. Work for rupture (in Newton"meter) of the osmotically dehydrated and dried pineapple samples, treated with irradiation, throughout storage

\begin{tabular}{lllll}
\hline $\begin{array}{l}\text { Time (days) } \\
\text { Radiation doses }\end{array}$ & 0 & 14 & 28 & 56 \\
\hline $0 \mathrm{kGy}$ & $0.5^{\mathrm{aA}} \pm 0.2^{*}$ & $0.49^{\mathrm{aA}} \pm 0.09$ & $0.26^{\mathrm{aB}} \pm 0.06$ & $0.21^{\mathrm{aC}} \pm 0.05$ \\
$0.75 \mathrm{kGy}$ & $0.39^{\mathrm{bA}} \pm 0.09$ & $0.34^{\mathrm{bA}} \pm 0.05$ & $0.16^{\mathrm{cB}} \pm 0.05$ & $0.10^{\mathrm{cC}} \pm 0.03$ \\
$1.5 \mathrm{kGy}$ & $0.29^{\mathrm{cA}} \pm 0.05$ & $0.21^{\mathrm{cB}} \pm 0.05$ & $0.21^{\mathrm{bB}} \pm 0.05$ & $0.14^{\mathrm{bC}} \pm 0.05$ \\
\hline
\end{tabular}

At a given column, equal letters in different lines (lowercase letters) indicate that there is no significant difference $(p<0.05)$ between the different radiation doses. At a given line, equal letters in different columns (capital letters) indicate that there is no significant difference ( $\mathrm{p}$ $<0.05)$ between the storage times.

A lowering of the values can be observed, for both rupture strength and work, throughout time, for all the studied radiation doses. This results show that the texture of the dried pineapple was influenced by the storage time as much as by irradiation. Textural quality loss in fruits is a result of the changes in the content of pectin and other cell wall polymers (during ripening), but also a result of the action of enzymes of cell wall degradation [16], which can have their action increased or reduced depending on the processing, such as cooking (accelerates enzyme action) and refrigeration 
(reduces enzyme action). Therefore, the fact that a softer texture was observed for the irradiated samples can be an indicative that the irradiation process has an effect on these enzymes, causing an increased activity on them. Also, since the pineapple fibers contribute to the firmness and cohesion of the product, it is likely that the irradiation could have affected the fiber structure, reducing their cohesion.

\section{Conclusion}

Irradiation affected the color (darkening) and the texture (softening) of osmotically dehydrated and dried pineapples, but it did not affect physical-chemical characteristics of the product. Therefore, the irradiation process, at radiation doses of up to $1.5 \mathrm{kGy}$, proved to be a good preservation method for the product.

\section{Referências}

[1] AZARAKHSH, N.; OSMAN, A; GHAZALI, H. M.; TAN, C. P.; ADZAHAN, N. M. Lemongrass essential oil incorporated into alginate-based edible coating for shelf-life extension and quality retention of fresh-cut pineapple. Postharvest Biol Tecnol, v. 88, p. 1-7, 2014.

[2] SILVA, W. P.; SILVA, C. M. D. P. S.; LINS, M. A. A.; GOMES, J. P. Osmotic dehydration of pineapple (Ananas comosus) pieces in cubical shape described by diffusion models. LWT-Food Science and Technology. v. 55, p. 1-8, 2014.

[3] SIMPSON, R.; RAMÍREZ, C.; BICHMEIER, V.; ALMONACID, A.; MORENO, J.; NUÑEZ, H.; JAQUES, A. Diffusion mechanisms during the osmotic dehydration of Granny Smith apples subjected to a moderate electric field. $J$ Food Eng, v. 166, p. 204-211, 2015.

[4] SILVA, K. S.; FERNANDES, M. A.; MAURO, M. A. Effect of calcium on the osmotic dehydration kinetics and quality of pineapple. J Food Eng, v. 134, p. 37-44, 2014. 
[5] VALENTE, P. P. S. S. Desidratação osmótica e secagem de Abacaxi (Ananás comosus (L.) Merril), variedade Pérola. Dissertação de Mestrado. Universidade Estadual de Campinas, Campinas, 2007.

[6] FRANCOSO, I. L. T.; COUTO, M. A. L.; CANNIATTI-BRAZACA, S. G.; ARTHUR, V. Alterações físico-químicas em morangos (Fragaria anassa Duch.) irradiados e armazenados. Food Sci Technol, v. 28, n. 3, p. 614-619, 2008.

[7] HERNANDES, N. K.; CONEGLIAN, R. C. C.; GODOY, R. L. O.; VITAL, H. C.; FREIRE JUNIOR, M. Testes sensoriais de aceitação da beterraba vermelha (Beta vulgaris ssp. vulgaris L.), cv. Early Wonder, minimamente processada e irradiada. Food Sci Technol, v. 27, p. 64-68, 2007.

[8] SILVA, J. M.; SILVA, J. P.; SPOTO, M. H. F. Características físico-químicas de abacaxi submetido à tecnologia de radiação ionizante como método de conservação pós-colheita. Food Sci Technol, v. 28, n. 1, 2008.

[9] ICGFI. International Consultative Group on Food Irradiation. Facts about food irradiation, 1999. Available in: http://www.iaea.org/nafa/d5/public/ foodirradiation.pdf. Access on: jan/2010.

[10] FELLOWS, P. J. Tecnologia do processamento de alimentos - Princípios e prática. Porto Alegre. Artmed, 2 ed., 2006.

[11] INSTITUTO ADOLFO LUTZ. Normas analíticas do instituto Adolfo Lutz V. 1: Métodos químicos e físicos para análise de alimentos. São Paulo. Ed IMESP, 3 ed., 1985.

[12] DiOnello, R. G.; BerberT, P. A.; MOLINA, M. A. B.; VIANA, A. P.; CARLESSO, V. O.; QUEIROZ, V. A. V. Desidratação por imersãoimpregnação de abacaxi em soluções de sacarose e em xarope de açúcar invertido. Food Sci Technol, v. 27, n. 4, p. 701-709, 2007.

[13] OLIVEIRA, M. Efeito da composição química, origem e grau de maturação sobre a cor e a crocância da banana nanica obtida por secagem HTST. Dissertação de Mestrado. Universidade Estadual de Campinas, Campinas, 2007. 
Revista Ciências Exatas e Naturais, Vol. 17, n² 2, Jul/Dez 2015

[14] SATO, A. C. K.; CUNHA, R . L.; ARGANDOÑA, E. J. S. Avaliação da cor, textura e transferência de massa durante o processamento de goiabas em calda. Braz J Food Technol, v. 8, n. 2, p. 149-156, 2005.

[15] FONTANA, A. J. Appendix D: Minimum water activity limits for growth of microorganisms. In: BARBOSA-CÁNOVAS, G. V.; FONTANA, A. J.; SCHMIDT, S. J.; LABUZA, T. P. (eds.). Water Activity in Foods: Fundamentals and Applications. Oxford. Blackwell Publishing Ltd, 2007.

[16] CHITARRA, M. I. F.; CHITARRA, A. B. Pós-colheita de frutos e hortaliças: fisiologia e manuseio. Lavras. ESAL, FAEP, 1990. 